\title{
Women's Rejection toward Patriarchy Culture: A Feminism Study in Selected Indonesian Novels
}

\author{
Yasnur Asri \\ Faculty of Languages and Arts \\ Universitas Negeri Padang \\ Padang-Indonesia \\ Yasnurasri5@gmail.com
}

\begin{abstract}
The focus of this study is on the form and the motif of women rejection toward the product of patriarchy culture. Method of the research is descriptive-analysis by taking data sources from six selected Indonesian novels. The purpose of this study is to describe the form and the motif of women's rejection toward patriarchy culture that presented in Indonesian novel based on grand feminism theories. The result of the analysis shows that women in the novels reject five cultural products of patriarchal ideology. The five products are (1) pingitan, (2) restriction on employment, (3) shotgun marriage, (4) domestic and sexual violence and (5) polygamy. The act of rejection manifests in three forms: (1) the radical rejection, (2) compromised rejection, and (3) compromised rejection with political, economical and socio-cultural strategies. The rejection occurs because patriarchy still positioned the women under the domination of men as the controllers. Men are still positioned as panatapraja (country controller) and pranatama (religion controller). Second, the rejection motif of women characters toward patriarchy culture is because there is no ownership of rights for women for their body and soul, such as beauty, virginity, mate, and marriage which are always determined by men.
\end{abstract}

Keywords-women's, rejection, patriarchal culture, feminism, Indonesian, novels

\section{INTRODUCTION}

There are some reasons that underlie the idea that why it is important to study women's rejection toward patriarchy ideology in Indonesian novels. First, in the context of feminism study, it is stated that the social role of women and men is controlled by a culture known as patriarchy culture. According to Walby (1989:213-220) patriarchy is a system in a social structure, a practice that placed men in a dominant position, to oppress and exploit women. In practice, patriarchy culture expansion happened in private field such as family and religion then extent to the country. This expansion caused the patriarchy dominate the rights of women. In Indonesia, the pariacrhy culture is tightening in a law of marriage No. 1 year 1974 . It becomes a tactic of the authority to civilize the patriarchy for the next generations. In Article 31 subsection 3 of the law stated that husband has a role as the head of a family and wife as a housewife. In this law is stated that the husband responsible to protect his wife and fulfill the living expense based on his capability (article 34 subsection 1), meanwhile the wife is responsible to manage the house chores (article 34 subsection 2). Depart from the laws, it is clear that the role of women in official way is only in domestic field to serve her husband well. Arivia (2006: 437) stated that the roles of women are just to manage the house chores such as cleaning the house, washing the clothes, cooking, taking care of the children and serving the husband.

Second, a well growth of patriarchy culture in Indonesia is interesting to be studied, including the feminism issues about the idea of gender-equality for women. Feminism issues are recently discussed in many fields, for instance, placed the women in a private field and the men in public field. The private field is placed the women as wives and mother. As a wife, a woman is expected to accompany her husband and support him. Thus, woman is expected to be well-behave and take care of herself. As a mother, a woman is not only expected to have children but also to make her children grow well and success. If a woman cannot give a child, she will not judged well by the society. It such a sad situation, in one side a mother is a person that is respected but in other side, a mother is placed as subordinate human being under the men. Whereas, none of Indonesian society can deny that woman is the pillar in a family.

The expression of "surga itu di telapak kaki ibu", (heaven is under mother's sole of feet), in patriarchy culture context is just as legitimation of the noble of mother. In Islam, woman is placed as the first human being that must be respected. However, in patriarchy culture, they always being neglected, especially when they take part in public field, they can easily lost her job after giving a birth with the reason that they leave the works in long time or the right to get protection.

These situations stressed the women that they must follow the role in the system of patriarchy as housewives. In partriacrhy culture, men are responsible for the children, however every mistake in nurturing process always complaint to the mother (women), similarly if the family do not have any children. Thus, in the perspective of patriarchy culture, there is no more urgent thing than educate their children.

The condition makes women rejected the product of partriachy culture, such as pingitan, restriction on employment, shotgun marriage, domestic and sexual violence and polygamy. The braveness of the women to make migration and work abroad, for example, indicates that women reject the deconstruction of rigid social-family. These phenomena show us that women rejected patriarchy culture that just placed them to work in dometical and private field. Attempts to move aside the women's role from domestic to public filed done by feminisms are important sign of social-reality, economy and political development. However, 
they still get a hard challenge since their rights always get used by the men for individual importance. In this process, the women are the victims. They become a tool in distributing products and life styles.

Third, in the society that keeps patriarchy culture, power is always controlled by men. Women just have a slight influence in society and it can be said that they do not have any rights in public and society. They depend on men in economical, social, political and psychological way especially in the marriage bond.

Thus, women are placed in subordinate or inferior position in family and society. They must do the job in domestic field; take care of the husband and children. This domestic field is placed for the women in patriarchy culture system.

The limitation of women's role by the partriarchy culture makes the women in fetters. Patriarchy culture give authority and domination to men in family and society life. Beside, the stereotype of women's body is also makes the condition worse. Men's domination toward women that happens gradually can influence women's mental condition. They have to obey the men's rules with the concept of beauty for them, so the women compete to take care of their body and make themsels beautiful. Women are just the second creature that accidentally born after the men. When the woman cannot get the beauty, they will not loved by a man especially and the society in general. It can make women depressed.

Domination and isolation toward women in partriarchy culture are not only happen in real life but also created in literary works especially novels. Novel is one of literary works that is used by the author to describe, expressed and criticized reality of social in life. The relationship of one person with another, between woman and man in society also happen in novels which is representated through thought, dialog, utterance and action done by the characters in the stories. Authors tell the story of how the relationship of one character with other characters, the characters with the society. Differ conflicts are also created in novels.

Fourth, the study of women's rejection toward patriarchy culture in Indonesian novels was not done much yet. Based on the rebiew of related findings, there are some relevant studies. They are (1) study done by Tineke Hellwig (2003) entitled " Citra Perempuan dalam Sastra Indonesia”. Based on the study, it can be concluded that essentialism identity has been a central issue for a long time related with women's emancipation in Indonesia. It is proved by the number of men's author that consider feminism as something that is ideal for women. Women's characters in men's author novel in Indonesia is still describes as the motherly character, caring, gentle dan able to take care of a family well. Other findings in this research is women's characters described by women's author. Feminism is always imaged as women's eternal subordination. (2) Study done by Wiyatmi (2003) entitled "Feminisme dan Dekonstruksi terhadap Ideologi Patriaki dalam Novel Saman Karya Ayu Utami". This study found that women's characters in the novel entitled Saman written by Ayu Utami represent a woman that refuse to partriarchy ideology in society. (3) The study done by Wiyatmi (2012) entitled "Citraan Perlawanan Simbolis terhadap Hegemoni Patriakat dalam Bidang Pendidikan dan Peran Perempuan di Sektor Publik dalam Novel-novel Indonesia." In her study Wiyatmi found that the rejection toward partriarchy hegemony done by the women's characters in Indonesian novels is done in order to get the chance to get the education and take a role in public field as working woman or as the activist in women's organization. (4) The study done by Barbara Hatley ( 2006) entitled "Pasca Kolonialitas dan si Feminim dalam Sastra Indonesia Modern". By taking the novels in 20 -ies century as the object of the study, Barbara found that women's characters faced difficulties in doing emancipation. These difficulties can be overcome with their education and colonial culture influence (Europe), so that they can have a modern family life. (5) Study done by Yasnur Asri (2012) entitled Representasi Ideologi Perempuan Minangkabau dalam novel Negeri Perempuan Karya Wisran Hadi. There are two findings in this study, two ideologies inside Minangkabau's women namely social ideology as the product of partriarchy culture and politic ideology. Social ideology in this novel is that the Minangkabau women are not allowed to be a penghulu (leader) in tradition. Meanwhile the ideology reflected in this novel has two patterns, positive and negative political ideology. Positive ideology can be seen from the activities of kingdom inherit family, meanwhile negative ideology is supported by the family beyond the kingdom. These form of ideologies trigger internal conflict (women inherit of the kingdom) with external conflict (wives of the official and rich person). It happened because the women inherit of the kingdom with feudal ideology do not want the kingdom taken care by the person ouside the kingdom family. In "Negeri Perempuan" which has democratic ideology, egalititarian and keep the matrilineal culture considers all the human being are the same, but because of the external influence, it change into idealism and neofeodal in partriarchy culture, and (6) study done by Yasnur Asri (2013) entitled “The Representation of Javanese Women's Rejection Toward Patriarchy Ideology: A Study of Existential Feminsm Toward Rara Mendut Novel by YB. Mangunwijaya. In this study, there are three forms of women's rejection found in this novel toward partriarchy ideology. The three forms of rejection are rejection in radical way, compromise and compromise in political, economy and socio-culture strategies. The motiv of women's rejection toward partriarchy culture is because women do not have rights for their own body and soul. Beauty, virginity, mate and marriage are always determined by the noble men. The attempts of rejection done by the women's character is still not give a maximum result yet because they do not get any support from partriarchy ideology and also the country that still make women in the position under the man as the power control. Men are still placed as panatapraja (country's control) and pranatama (religion's control). The different of this present study with the previous is not only on the focus of the study but also on the source of the data, mthod and grand theory used.

Based on the four reasons above, the focus of this research is on the form of women's rejection in Indonesia toward product of partriarchy culture representated in Indonesian novels.

\section{MethoD}

This study is a descriptive qualitative research using descriptive analitive method. This study aims to describe and understand the form of women's rejection toward partriarchy culture reflected in Indonesian novels. The source of data in this study is 6 selected novels entitled; Azab dan Sengsara as the representation of Tapanuli's societ, Sitti Nurbaya as the 
representation of Minangkabau's society which has matrilineal system, Kehilangan Mestika s as the representation of Bangka's society, Para Priyayi as the representation of Javanese' society, Perempuan Berkalung Sorban (representation of Indonesia nowadays), and Namaku Teweraut as the representation of Papua's society. These novels are selected randomly. Meanwhile, the soft data of this study is words, phrases, sentences, dialogs and utterances of the characters or narrator that contains the information related to women's rejection toward partriarchy ideology. The data analysis is done through descriptive qualitative technique in form of inventarisation, categorization, tabulation and inference. Inventarisation is done to inventarised all the data related with the women's rejection toward partriarchy culture, which are used as the object of the study. Categorization is used to categorize the data based on the category chosen. Tabulation is used to summarize all data and inference is used to interpret and conclude the result of the study based on the research question. In this study, inference is done based on the framework theory of literary sociology, text interpretation and feminism.

\section{FINDING AND DISCUSSION}

Based on the identification and clarification of the data, there are five indicators of partriarchy culture product that are rejected by women in Indonesia which is reflected in the novels. These five products are (1) pingitan, (2) restriction on employment, (3) shotgun marriage, (4) domestic and sexual violence and (5) polygamy.

The rejection toward the pingitan tradition is found in Azab dan Sengsara, Sitti Nurbaya, and kehilangan Mestika novels. The restriction on employment in private and public sector is found in Azab dan Sengsara, Sitti Nurbaya, and kehilangan Mestika novels, shotgun marriage is found in Azab dan Sengsara, Sitti Nurbaya, Para Priyayi, Perempuan Bekalung Sorban, dan Namaku Teweraut novels, domestic and sexual violence can be found in Azab dan Sengsara, and Perempuan Bekalung Sorban novels and polygamy is found in Sitti Nurbaya, Kehilangan Mestika, Perempuan berkalung Sorban, and dalam novel Namaku Teweraut novels. More explanation of these findings can be seen in the Table 1 .

Table 1. Women's Rejection Toward the Product of Patriacrhy Culture

\begin{tabular}{|c|l|c|c|c|c|c|c|}
\hline \multirow{2}{*}{ No. } & \multicolumn{1}{|c|}{$\begin{array}{c}\text { Women's rejection toward the } \\
\text { patriarchy culture }\end{array}$} & \multicolumn{5}{|c|}{ Novel } \\
\cline { 3 - 8 } & & AZS & SN & KM & PR & PBS & TWR \\
\hline 1. & Pingitian & V & V & V & V & - & - \\
\hline 2. & Restriction on employment & V & V & V & V & - & - \\
\hline 3. & Shotgun marriage & V & V & - & V & V & V \\
\hline 4. & Domestic and sexual violence & V & V & - & - & V & - \\
\hline 5 & Polygamy & - & V & V & - & V & V \\
\hline
\end{tabular}

In which:

$A Z S=$ Azab dan Sengsara

$S B=$ Sitti Nurbaya

$K M=$ Kehilangan Mestika

$P R=$ Priyayi

$P B S=$ Peremmpuan Berkalung Sorban

$T W R=$ Teweraut

Moreover, based on the data classification and tabulation in general, it is found that there are 195 women's rejection toward partriarchy culture, the data are as follow: (1) pingitan 38 data, (2) restriction on employment 55 data, (3) shotgun marriage 49 data, (4) domestic and sexual violence 19 data and (5) polygamy 34 data. The details of each indicator in each novels can be seen in the Table 2 .

Table 2Data Freqency of Women's Rejection toward Partriarchy Culture for Each Indicator

\begin{tabular}{|c|c|c|c|c|c|c|}
\hline \multirow[t]{2}{*}{ NO. } & \multirow[t]{2}{*}{ NOVELS } & \multicolumn{5}{|c|}{$\begin{array}{l}\text { PRODUCT OF PARTRIARCHY CULTURE REJECTED BY THE } \\
\text { WOMEN }\end{array}$} \\
\hline & & Pingitan & $\begin{array}{l}\text { Restriction } \\
\text { on } \\
\text { employment }\end{array}$ & $\begin{array}{l}\text { Shotgun } \\
\text { Marriage }\end{array}$ & $\begin{array}{c}\text { Domestic } \\
\text { and sexual } \\
\text { violence }\end{array}$ & polygamy \\
\hline 1. & Azab dan Sengsara & 8 & 20 & 22 & 5 & - \\
\hline 2. & Sitti Nurbaya & 6 & 11 & 5 & 3 & 2 \\
\hline 3. & Kehilangan Mestika & 16 & 19 & - & - & 6 \\
\hline 4. & Priyayi & 8 & 5 & 9 & - & - \\
\hline 5. & $\begin{array}{l}\text { Peremmpuan } \\
\text { Berkalung Sorban }\end{array}$ & - & - & 13 & 11 & 19 \\
\hline 6. & Teweraut & - & - & 10 & - & 7 \\
\hline & Total & 38 & 55 & 49 & 19 & 34 \\
\hline
\end{tabular}




\section{DISCUSSION}

Based on the findings above, one of the forms of partriarchy culture product that is rejected by the women is pingitan tradition. Data frequency that is found in this study is 38 data. In the novels contains of pingitan tradition it is told that there is a tradition where a 12 years old girl should stay at home until she got her mate. This tradition is happen almost in all district in Indonesia. This phenomena is reflected in Indonesian novels entitled Azab dan Sengsara, Sitti Nurbaya, and Kehilangan Mestika. As the illustration of the phenomena related to the women's rejection toward pingitan can be seen in the clip of the novel as follow.

"Riam, it seems that you see the men as a good human being than women?" "It is" Mariamin said, "If I were a man, I am capable to work as angkang; I will be happy since I can go anywhere during my time, going anywhere, to Deli to find a job. It is different with us as a woman; we must stay at home, not allowed to go outside the home. (AZS/data number 5)

Based on the quotation above, it can be seen that pingitan tradition drawn in the story of the novels represent the reality happen in the society and it shows an indication that Indonesia still dominantly influence by the partriarchy culture. In the novels in this study there is an attempt to reject and show the bad effect of the tradition. The phenomena emerged because the tradition is not suitable with the modernity value and idea that support the individualism rights and also not suitable with the gender equality.

Based on the feminism literary criticism perspective, rejection, resistance and struggle of the women's characters in several novels show the rejection toward gender unequality that limit their freedom. Some women's character that is already get good education, with the help from men, eager to voiced feminism especially liberal feminism that give right and freedom to the women to get education and plan for their future and also to choose their husband.

The second finding about partriarchy is the restriction on employment. In Indonesia, men are placed in public sector meanwhile women are in domestic sector. It is proved that society point of view reducted the women. Thus, it can be said that in context of Indonesian, the role of women from time to time cannot reach the equality of gender with men. Many things can be observed from this assimetric relationship. In family, for example, women are responsible in nurturing the children and serving the husband. In the public sector, women got less job opportunity than men.

In source of the data it is also found that women just have the duty or responsible for the family only, the the title "a housewife". Housewives all over the world do many house chores related to the family. They are nurturing the children, cooking for the family, washing clothes, etc. They also help in earning oney to fulfill the living expense such as knitting and making handycraft, as long as their main duty does not neglected. House chores is one of the division of job based on gender, in which men tend to do the job that get paid, meanwhile women do the job that do not get paid.

Women are judged as good housewives since they do not reach higher education program and also the stereotype that women must stay at home and take care of the family. It is because, in the stereotype, men are the head of the family to earn money for family.

There are 55 data that are found related with restriction of employment domestic and public. For example, in novel entiled Kehilangan Mestika written by Hamidah told the story about a girl named Hamidah, she came from a common family in Mentok, Bangka Island who get the opportunity to get education in Normal School for girl, then she become a teacher. Hamidah's father see that education is very important for a woman in order to make her free from the limit of partriachy culture.

I will continue my study in Sekolah Normal Putri in PadangPanjang like my siblings. When I leave father and the town for the first time and get a new sea journey make me feel worry. At the beginning, I feel guilty to leave hometown, but father want to see his daughter to be a better person in the future and have a good behavior (KM/ data number 3)

The third rejection done by the women is a shotgun marriage. There are 49 data found in the novels. It can be seen in the following quotation of a novel Azab dan Sengsara as follow.

I am forced to marry a man that I do not love, maybe the love and affection can appear after the marriage, but the man is too old... we have twenty year old differ of age, I am taken to Palembang.. ah, I do not need to explain it, then I ran away to Betawi, go back home to Bandung, my parents passed away there, I do not have place to live in, I stay in different

hotels, move from one city to another. (AZS/ data number 14)

Based on the quotation above, it can be understood that parents force their daughter to marry a man that she does not know and love. Moreover, the man is too old for her and has bad personality. That is why the woman ran away from her husband.

Different with the shotgun marriage told in the story of Azab dan Sengsara, in Para Priyayi novel, it is told that Soemini can delay her shotgun marriage arranged by her parents with Raden Harjono, by giving condition that she want to continue and finish her study to Van Deventer Schooll. Soemini does not reject the shotgun marriage but she reject to get married under the age of 15 .

The shotgun marriage under the age is also happened by Anisa in Perempuan Berkalung Sorban novel. After graduating from her elementary school, Anisa is forced to marry the son of her father's bestfriend; she is still 13 years old. According to Marriage Law (UU No 1, year 1974), article 7, a marriage is allowed if the man at least in the age of 19 and the woman at least in the age of 16. Thus, Anisa's father broke the Marriage Law. Anisa is not only be a victim of shotgun marriage but also force to marry a man that she does not know.

Partriarchy power in this case is done by Anisa's father. Anisa does not get any chance to know her candidate husband, they just met each other an hour before the marriage vow. There is a rebellion done by Anisa, but her father's power is too strong. She must follow what her father's want to marry a man named Samsudin. Even Samsudin has a rough character and usually do a physical, sexual and psychological abuse. The title of a novel itself, symbolicly contain the meaning of fetter of women from partriarchy power which is symbolize in form of sorban, a wide head piece of cloth. 
Shotgun marriage is also found in the novel entitled novel Namaku Teweraut. Character of Teweraut and Sisilia must obey what their parents want to get married with the man that they do not know. Both of them do not have any rights to reject their parents want eventhough teweraut become the seventh wife and Sisilia the sixth wife. Teweraut and Sisilia's father directly accept the proposed from the man that want his child to be his wives without asking permission to them. The status as the head of the town makes the girls father resists to reject him as son in law for both of his daughters. In the novel, it is also stated that Teweraut family is so proud that their daughters are married with Akaptis, the head of a small town, and give many bridgeprice. It is shown that the value of a men in Asmat society, Papua is determined by the social status and wealth.

The fourth problem that rejected by a woman is domestic and sexual violence. In this study, there are 19 data that support this problem. The problem reflected in a novel entitled Azab dan Sengsara and Perempuan Berkalung Sorban. In the novel Azab dan Sengsara told that after Mariamin got married with Kasibun and live in Medan, Mariamin know that his husband suffer sexual disease, so that to prevent from this disease, Mariamin refuse to have a sex with her husband. As a result she was oppressed by him.

After experienced dometic and sexual violence, Mariamin report what her husband done to her to the police. The police then investigate the case and Kasibun get punished and pay fine for twenty five rupiah and they divorced.

In front of the police office, Mariamin's carriage stop. She get down and walk without hesistate. From her cloth, it is known that she is Batak person. The police get Mariamin inside and she tell all the story of domestic and sexual violence done by her husband. Before the case close, she stay in penghulu's home.

Mariamin's brave to refuse to have a sex with her husband to prevent from sexual disease from her husband and report him to the police are related with her education. Mariamin has an awareness about her existence, when she got an unfairness, she resists.

Moreover, in Perempuan Berkalung Sorban novel, Anisa also experienced domestic and sexual violence from her husband. Anisa is a girl who is a victim of violence and shotgun. In a young age, she is forced to marry a man that she never know. Her husband doe not have any occupation and cruel "Plak! Plak! Ia menampar mukaku bertubi-tubi hingga pipi dan leherku lebam kebiru-biruan. Untuk pertama kali, kucakar wajahnya dan ia membanting badanku ke lantai. Bu nyi gedebug dan suara berisik di kamar membuat Kalsum curiga. Ia menggedor pintu dengan ketakutan dan Samsudin membentaknya...”(PBS/data nomor 15).("Plak!Plak! he slaps my face till my face and neck get wound. For the first time, I scratch his face and he thrown down my body to the floor. The noise make Kalsum suspiscious and knock on the door and Samsudin yell at her (PBS/ data number 15)

Besides experienced physical violence, Anisa also experience sexual violence from her husband. She tell it to her sibling and parents. Her parents then makes her get divorced. Her parents apologize for forcing her to get married with the man that she does not know at young age.

Violence toward women, as stated in Regulation (Undang-undang) Number 7 year 1984 about the Convention of the Abolition of all form os Discrimination toward women, is the action that caused suffer including threat, force and the seize of freedom in public and private sector (article 1 and 2). Moreover, in article 2, the regulation stated that violence toward women including physical, sexual and psychological in family, it is including sexual violence to daughter in domestic and sexual violence.

Domestic and sexual violence according to PKDRT regulations is every action toward someone, especially women, that cause suffer in physical, sexual and psychology side, the threat to force someone to do something, seize the freedom in family (article 1, subsection 1). In the regulation, (article 1 subsection 2) stated it fro all family member; a husband, wife and children (including step and adopted children); relation that create from marriage and also the workers in the house/family.

Moreover, the fifth finding in this study is women's rejection toward polygamy. There are 34 data support the problem. Polygamy is considered as one of the partriarchy power in domestic field because it is happed around the family environment. Polygamy is found in the novels entitled Sitti Nurbaya, Kehilangan Mestika, Perempuan Berkalung Sorban, Geni Jora, and Namaku Teweraut. Polygamy is not only described in the novel but also criticized from the social perspective and religion especially Islam.

Polygamy is reputed legal if it is suitable with the regulation of marriage in Indonesia and Islam's law, in society there are polygamy marriage, which is not legal and not authorized and called nikah siri. Eventhough from the side of religion nikah siri is legal but based on the Regulation of Marriage Law in 1974, the marriage does not have any power in the law side.

In the law of marriage article 5, 6 and 7, stated that in order to make the marriage guaranteed, the marriage should be noted in Pegawai Pencatat Nikah (article 5). Marriage that is noted in Pegawai Pencatat Nikah does not have law power (article 6). The marriage is just can be proven by the marriage book.

In the novel entitled Sitti Nurbaya polygamy is mostly done by nobleman. They have point of view that polygamy is considered as the life style of nobleman. It is delivered by Putri Rubiah to Sutan Mahmud, her brother. Sutan Mahmud reject polygamy. Beside that, he does not obey Minangkabau's tradition about the relationship of children and father. In Minangkabau society that has matrilineal system, there is a rule that the children will be on the wife's side so that the father does not need to be responsible for them. In Kehilangan Mestika novel stated that Hamidah force to follow her husband to get married again since they do not have any children. Women who cannot give a child in partriachy become a weak person. She cannot reject when the husband want to get married and do polygamy. The position is recessive since the husband get married again and has children from the second wife, as the first wife with no children make Hamidah beshoved aside because the husband does not care of her anymore. Thus, Hamidah decide to tell her husband to get divorced with her. Initiation of getting divorced from Hamidah shows independent women to fight against men's power who did polygamy. 
Different with the previous two novels, polygamy is done based on the religion rules, polygamy in novel Perempuan Berkalung Sorban is told to be full of problems and ends with divorce. Husband is described as a scholar, does not have fix occupation and economically depend on his parents. Her wife allow the husband to do polygamy because the husband has an affair with another woman and makes her pregnant. The relationship between the first wives with the second wife is not harmonious.

Moreover, in Namaku Teweraut novel polygamy is happen in Asmat society. Polygamy is considered as tradition and life style of the men that have high social status like the head of an ethnic group. Teweraut's father, Desnam, does polygamy with two wives Cipcowut (Teweraut's mother) dan Cenakat. Teweraut's father is described as the person that has important social status in the society. He is the leader of war and clan that responsible for ritual, law and tradition. Teweraut is get married with the head of etnic group, Akatpits, as the seventh wife. At the time her father told her about the marriage, she tries to reject it but as the daughter she realize that her opinion will not be heard.

Polygamy that described in some novels in this study show that polygamy related with tradition background and partriarchy culture that consider men as the people who have power. In Minangkabau society in the past and in papua, polygamy was done by nobleman who have power and social status in the society, as the head of the town (Namaku Teweraut novel) or Penghulu (Sitti Nurbaya novel), but it is also happen because there is no legal marriage law that create chances for men to do polygamy. The motive rejection of women character toward polygamy is because of domination of partriarchy culture system that fetter women's freedom in physical possession, mate and marriage.

\section{CONCLUSION}

Based on the findings above, some things can be conluded. First, there are five form of rejections that are done by the women's character toward partriarchy reflected in Indonesian novels. These forms are (1) pingitan, (2) restriction on employment, (3) shotgun marriage, (4) domestic and sexual violence and (5) polygamy. These form of rejections done by the women's character, do not give a maximum result because it is supported by the partriachy culture and by the country that positioned women under the men as panatapraja (country controller) and pranatama (religion controller). Second, the motive of women's rejection toward partriarchy in Indonesian novels that fetter women's freedom in physical possession, mate and marriage. This study suggest that other studies are hoped to be done to demolish domination of other partriachy culture that is reflected in Indonesian novels by using other perspectives.

\section{References}

Arivia, Gadis (2006). Feminisme Sebuah Kata Hati. Jakarta: Penerbit Buku Kompas.

Asri, Yasnur, (2012) “Representasi Ideologi Perempuan Minangkabau dalam novel Negeri Perempuan Karya Wisran Hadi.” jurnal Humaniorma Volume 25 No. 1. Yogyakarta: Fakultas Budaya Universitas Gajahmada.

Asri, Yasnur, (2014)." The Representation of Javanese Women's Rejection Toward Patriarchy Ideology: A Study of Existential Feminsm Toward Rara Mendut Novel by YB. Mangunwijaya. The International Journal of Social Sciences and Humanities Vol. 1 Isu 6 tahun 2014

Asri, Yasnur, (2012) “Women'S Struggle toward Gender Unfair: A Study Case in Indonesian Novel” journal of “Language and Literature Studies Vol. 2 No. 7 tahun 2014

Fakih, Mansoer, (2006). Analisis Gender \& Tranformasi Sosial. Yogyakarta: Pustaka Pelajar

Hamidah, (1959). Kehilangan Mestika. Jakarta: Balai Pustaka. Cetakan ke-2. (Cetakan Pertama 1935).

Hatley, Barbara, (2006). "Pasca Kolonialitas dan si Feminim dalam Sastra Indonesia Modern,” dalam Foucher, Keith dan Day, Tony (penyunting). 2008. Clering a Space. Jakarta: Yayasan Obor Indonesia dan KITLV. Halaman 189-223

Hellwig, Tineke, (2003). Citra Perempuan dalam Sastra Indonesia. Jakarta: Women Research Institute dan Desantara.

Kayam, Umar. (1992). Para Priyayi. Jakarta: Grafitipers. Cetakan ke-2.

Khalieqy, Abidah El. (2001). Perempuan Berkalung Sorban. Yogyakarta: Yayasan Fatayat NU.

Rusli, Marah. (2001). Sitti Nurbaya. Jakarta: Balai Pustaka, cetakan ke-35 (cetakan pertama 1922)

Sekarningsih, Ani. (2000). Namaku Teweraut. Jakarta: Yayasan Obor Indonesia.

Siregar, Merari (1920). Azab dan Sengsara. Jakarta: Balai Pustaka.

Stowasser, Barbara, (1984). “The Status of Women in Early Islam”, dalam Freda Hussain (ed.). Muslim Women, New York: St. Martin's Press.

Undang Undang RI Nomor 1 Th. 1974 tentang Perkawinan. Diunduh dari http://www.lbh-apik.or.id/uu-perk.htm diunduh melalui www. google.com 8 September 2017.

Walby, Silvia (1989). "Theorizing Patriarchy." Sosiology Journal, Vol.23 (2) hal. 213-231.

Wiyatmi. 2003. "Feminisme dan Dekonstruksi terhadap Ideologi patriaki dalam Novel Saman karya Utami,” Diksi, Volume 10 No.2, Juli 2003.

Wiyatmi. 2012. "Citraan Perlawanan Simbolis terhadap Hegemoni Patriakat dalam Bidang Pendidikan dan Peran Perempuan di Sektor Publik dalam Novel-novel Indonesia,” dimuat dalam Kritik Sastra Feminis: teori dan Aplikasi dalam Sastra Indonesia. Yogyakarta: Penerbit Ombak. 